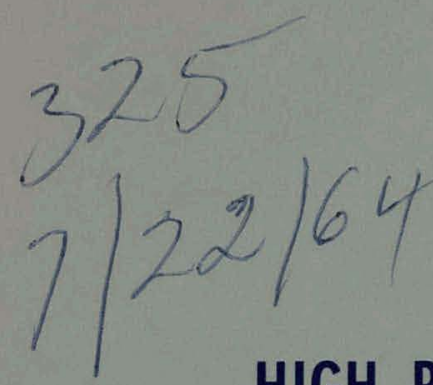

\title{
HIGH RESOLUTION AT LOW ENERGIES WITH AN IRON DOUBLE-FOCUSING BETA-RAY SPECTROMETER
}

\author{
I. Bergstrom, Y.Y. ChU, AND G.T. EMERY
}

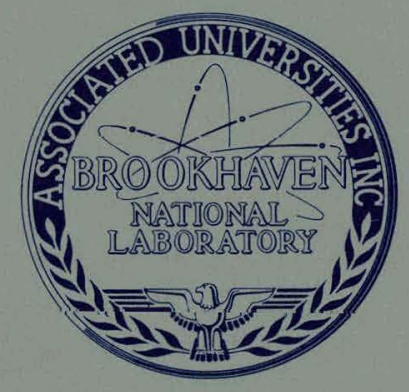

March 1964

BROOKHAVEN NATIONAL LABORATORY ASSOCIATED UNIVERSITIES, INC. under contract with lie UNITED STATES ATOMIC ENERGY COMMISSION 


\section{DISCLAIMER}

This report was prepared as an account of work sponsored by an agency of the United States Government. Neither the United States Government nor any agency Thereof, nor any of their employees, makes any warranty, express or implied, or assumes any legal liability or responsibility for the accuracy, completeness, or usefulness of any information, apparatus, product, or process disclosed, or represents that its use would not infringe privately owned rights. Reference herein to any specific commercial product, process, or service by trade name, trademark, manufacturer, or otherwise does not necessarily constitute or imply its endorsement, recommendation, or favoring by the United States Government or any agency thereof. The views and opinions of authors expressed herein do not necessarily state or reflect those of the United States Government or any agency thereof. 


\section{DISCLAIMER}

Portions of this document may be illegible in electronic image products. Images are produced from the best available original document. 


\section{HIGH RESOLUTION AT LOW ENERGIES WITH AN IRON DOUBLE-FOCUSING BETA-RAY SPECTROMETER \\ I. Bergstrom,* Y.Y. ChU, AND G.T. EMERY}

March 1964

*Visitor from Royal Institute of Technology and Nobel Institute of Physics, Stockholm, Sweden.

BROOKHAVEN NATIONAL LABORATORY UPTON, NEW YORK 
This report was prepared as an account of Government sponsored work. Neither the United States, nor the Commission, nor any person acting on behalf of the Commission:

A. Makes any warranty or representation, expressed or implied, with respect to the accuracy, completeness, or usefulness of the information contained in this report, or that the use of any information, apparatus, method, or process disclosed in this report may not infringe privately owned rights; or

B. Assumes any liabilities with respect to the use of, or for damages resulting from the usc of any information, apparatus, method, or process disclused in this report.

As used in the above, "person acting on behalf of the Commission" includes any employee or contractor of the Commission, or employee of such contractor, to the extent that such employee or contractor of the Commission, or employee of such contractor

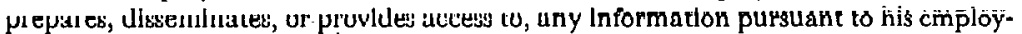
ment or contract with the Commission, or his employment with such contractor.

PRINTED IN USA

PKICE 50 CEEN'I'S

Available from the Office of Technical Services

Department of Commerce

Washington 25, D.C. 


\section{HIGH RESOLUTION AT LOW ENERGIES WITH AN IRON DOUBLE-FOCUSING BETA-RAY SPECTROMETER}

\section{INTRODUCTION}

Perlman and $\mathrm{McKeown}{ }^{1}$ have found that they could improve the resolution of an iron doublefocusing spectrometer of the Stockholm type by a factor of about 4 by adding shims of soft iron around the outside of the spectrometer. The shimming, however, was done to optimize the resolution for a conversion line of $624 \mathrm{keV}\left(\mathrm{Cs}^{137} K 662\right)$. It was not at all clear whether this shimming was then also optimum for lines of other energies; differences might be expected in the low-energy region, where remanence effects and effects of the earth's field may be significant.

It is difficult to investigate the instrumental line shape of electron spectrometers at low energies, because with most sources the energy loss in the source is the principal cause, or one of the principal causes, of the line width. For such an investigation the counter window must also be thin enough to transmit low-energy electrons. In all previous work with the Brookhaven double-focusing spectrometer, the sources were thick enough to dominate the line shape at low energies, and the counter windows did not transmit. electrons below $15 \mathrm{keV}$.

The availability of an electromagnetically separated source of $\mathrm{Kr}^{79}$ allowed the investigations reported here to be made. In the decay of $\mathrm{Kr}^{79}$ there is a $44-\mathrm{keV}$ transition (in $\mathrm{Br}^{79}$ ), with a $K$-conversion line at $31 \mathrm{keV}$, and there are $K L L$ Auger electrons at around $10 \mathrm{keV}$.

\section{COUNTER}

The flow proportional counters used in the spectrometer had previously had Mylar windows 580 $\mu \mathrm{g} / \mathrm{cm}^{2}$ thick, ${ }^{2}$ or even thicker, measuring $38 \times 19$ $\mathrm{mm}$. They had been operated with butene- 2 gas at a pressure of $25 \mathrm{~mm} \mathrm{Hg}$ and at a voltage of about $1500 \mathrm{~V}$.

In this work thin windows of VYNS, with an evaporated coating of gold to make them conducting, and of much smaller size $(12 \times 3 \mathrm{~mm})$ were used. Films $\approx 60 \mu \mathrm{g} / \mathrm{cm}^{2}$ thick, without support, with support on an $85 \%$ transmission tungsten mesh, and with support on a $55 \%$ transmission flat nickel foil were all tested, and the leak rates were such that the spectrometer pressure was up to about $10^{-3} \mathrm{~mm} \mathrm{Hg}$ when the counter gas pressure was up to $15 \mathrm{~mm} \mathrm{Hg}$.

It was then decided to determine (1) whether the pressure of the counter gas could be reduced, and (2) whether the higher gas pressure in the spectrometer due to the leaks affected the resolution and transmission of the spectrometer. It was found that good plateaus could be obtained at a counter pressure of $10 \mathrm{~mm} \mathrm{Hg}$ and even at $7 \mathrm{~mm} \mathrm{Hg}$. It was also found that, at an.energy of $31 \mathrm{keV}$ and a resolution of $0.19 \%$, the line shape was the same at a spectrometer pressure of $4.2 \times 10^{-4} \mathrm{~mm} \mathrm{Hg}$ and at $3.5 \times 10^{-6} \mathrm{~mm} \mathrm{Hg}$. Comparison plots are shown in Figures 1 and 2.

Finally, gold-coated VYNS films of $100 \mu \mathrm{g} / \mathrm{cm}^{2}$, with a very slow leak rate, were produced, and the final measurements were made with an unsupported window of one of these films. ${ }^{2}$ Some plateau curves taken with this counter are shown in Figure 3.

\section{SOURCE QUALITY}

The standard source used for aligning and testing the spectrometer was a vacuum-evaporated $\mathrm{Cs}^{137}$ source. The line width (full width at halfmaximum) at $624 \mathrm{keV}$ is $0.05 \%$ in momentum with a 3-cm-wide entrance baffle. There is a tail on the low-energy side of the line which may be due to aberrations and may be partly due to source thickness.

An electroplated $\mathrm{Te}^{121}$ source was used in the spectrometer. The line widths found (with $3-\mathrm{cm}$ entrance baffle, $0.65-\mathrm{mm}$ counter slit) were $0.05 \%$ at $500 \mathrm{keV}, 0.08 \%$ at $100 \mathrm{keV}$, and $0.3 \%$ at $30 \mathrm{keV}$. The source thickness is very important at low energies.

The $\mathrm{Kr}^{79}$ source was electromagnetically separated in the Stockholm isotope separator and collected on an electropolished aluminum platc with a retarding field such that the ions entered the plate with $\approx 1.5-\mathrm{keV}$ energy. The source was in- 


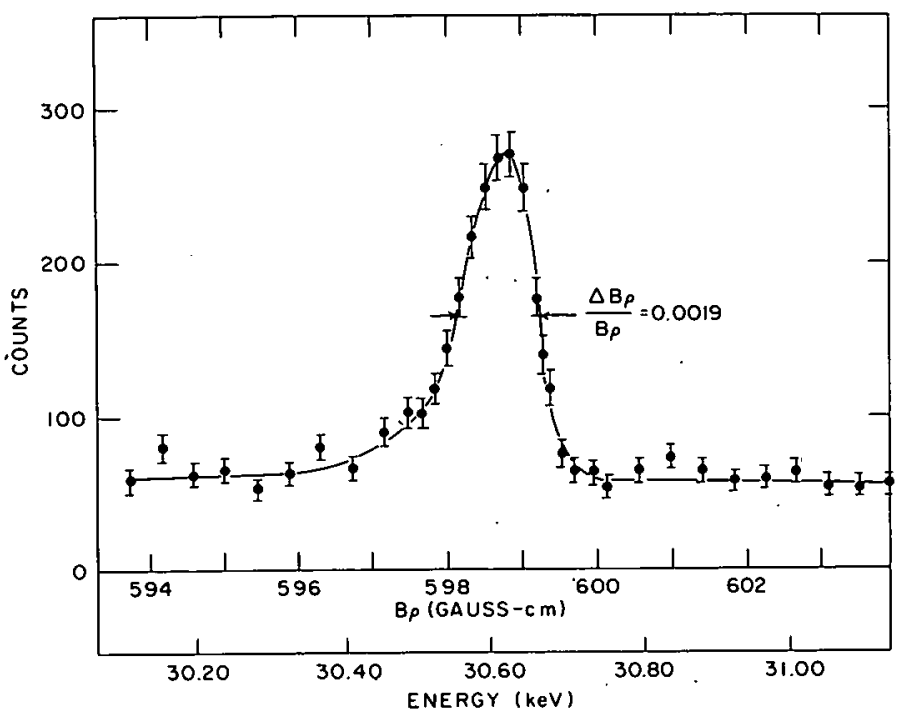

Figure 1. $K$-conversion electron line of the 44-keV transition in $\mathrm{Br}^{i 9}$ measured with the spectrometer pressure $=4.2 \times 10^{-4} \mathrm{~mm} \mathrm{Hg}$.

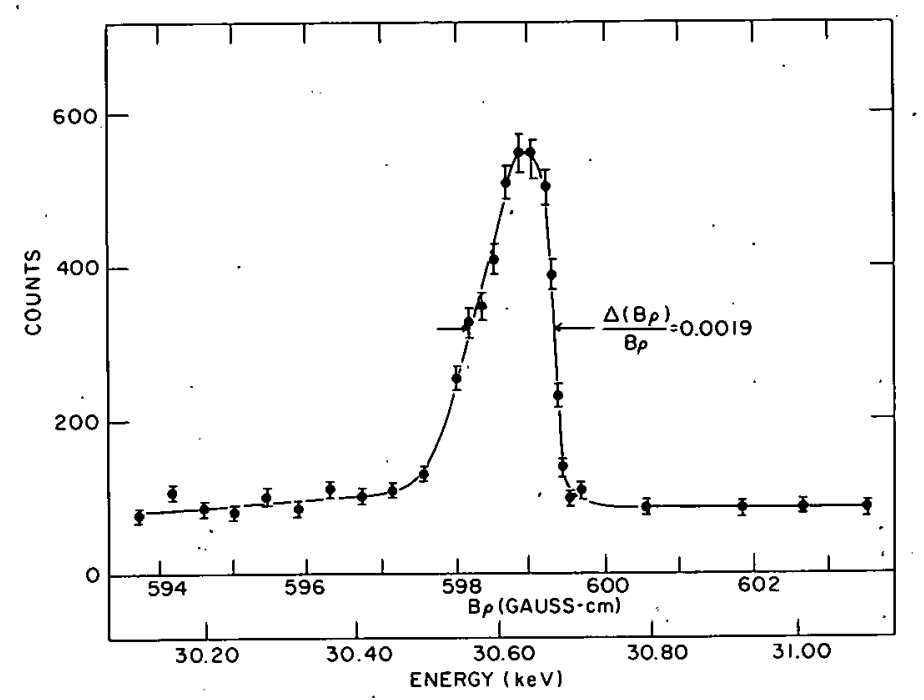

Figure 2. $K$-conversion electron line of the $44-\mathrm{keV}$ transition in $\mathrm{Br}^{79}$ measured with the spectrometer pressure $\log 3.5)\left(10^{-6} \mathrm{~mm} \mathrm{Hg}\right.$.

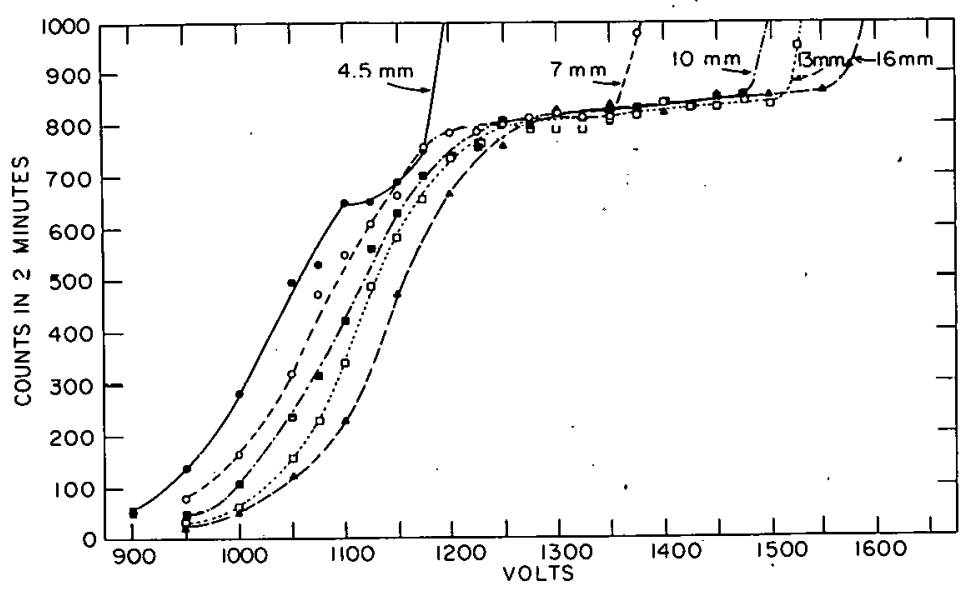

Figure 3. Plateaus of the proportional counter measured with different butene-2 gas pressures. visible. Autoradiograms showed it to be about 0.3 mm wide. Measurements ${ }^{3}$ of the range of krypton ions in aluminum lead to an expected median penetration depth of $\approx 0.5 \mu \mathrm{g} / \mathrm{cm}^{2}$.

When the entrance-baffle openings were reduced to give a line width of $0.08 \%$ at $10 \mathrm{keV}$, the satellite peaks due to plasmon excitation in the aluminum were clearly visible. The experimental spectrum of the $K L L$ Auger group will be discussed in the next section.

\section{SPECTROMETER}

With the standard $\mathrm{Cs}^{137}$ source the line width with 3 -cm-wide entrance baffle and $0.65-\mathrm{mm}$ counter slit is $=0.05 \%$. The vertical baffle opening is about $9 \mathrm{~cm}$ high in normal operation.

The $\mathrm{Kr}^{79}$ source was aligned with the help of autoradiograms. Initial rune with the standard baffle openings showed a line width of $0.18 \%$ at $31 \mathrm{keV}$ and $0.34 \%$ at $10 \mathrm{keV}$.

Reducing the entrance-baffle width to $1 \mathrm{~cm}$ gave a line width of $0.09 \%$ at $31 \mathrm{keV}$ and $0.19 \%$ at 10 $\mathrm{keV}$. Moving the location of the entrance-baffle opening radially $1 \mathrm{~cm}$ in and out gave little or no improvement. Reducing the baffle width to $0.5 \mathrm{~cm}$ gave no improvement at either 10 or $31 \mathrm{keV}$. Moving the source $2 \mathrm{~cm}$ nearer the entrance baffle seemed to give a slight improvement.

Reducing the vertical entrance baffles to an opening of $3.7 \mathrm{~cm}$ reduced the line width at $10 \mathrm{keV}$ to $0.08 \%$, which corresponds to $\approx 16 \mathrm{eV}$. A plot of a section of the $K L L$ Auger spectrum at $10 \mathrm{keV}$ is shown in Figurc 4.

The natural widths of the $K, L_{2}$, and $L_{3}$ levels in bromine are each about $2.0 \mathrm{eV} .{ }^{4}$ The $L_{1}$ level width is less accurately known, but the data of Geiger, Graham, and Merritt ${ }^{5}$ suggest that it is about $6 \mathrm{cV}$. Thus the $K L_{2} L_{2}, K L_{2} L_{3}$, and $K L_{3} L_{3}$ lines are expected to have the smallest natural width, and the $K L_{1} L_{1}$ line is expected to have the largest natural width. The $K L_{1} L_{1}$ line did indeed appear to be significantly broader than the others; a run with better statistics will be needed to confirm this.

The structure on the low-energy sides of the lines (see Figure 4) is expected from the discrete nature of the predominant energy losses for low-energy electrons (see ref. 5, for example). The characteristic peak in the energy-loss spectrum for $\mathrm{Al}_{2} \mathrm{O}_{3}$ is at about $20 \mathrm{eV} \cdot{ }^{6}$ For aluminum metal, it is only about $15 \mathrm{eV}$, but the surface of the source was un- 


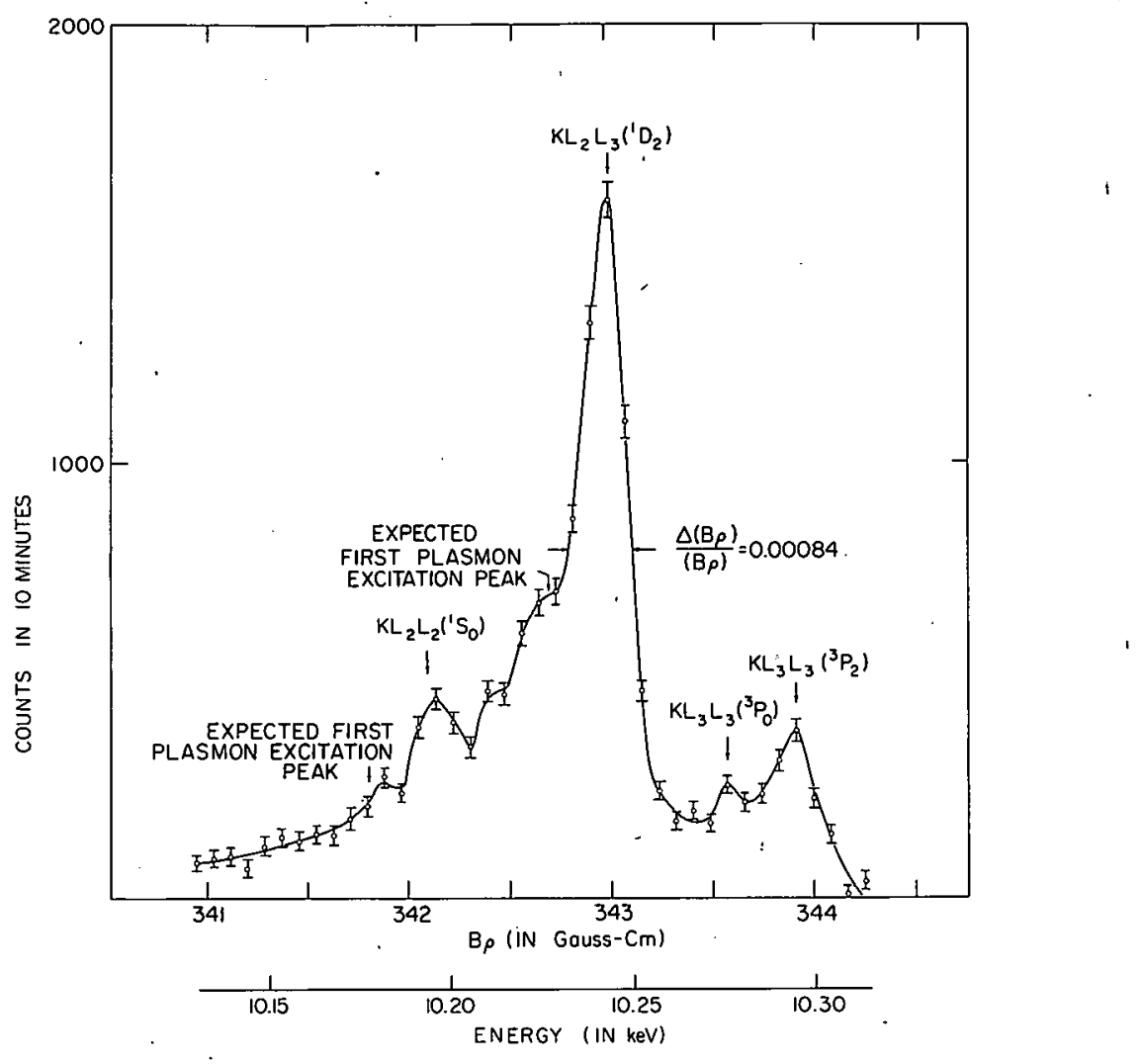

Figure 4. A section of the measured $K L L$ Auger electron spectrum of $\mathrm{Kr}^{79}$.

doubtedly well oxidized at the time the data were taken.

The final part of the investigation of the $\mathrm{Kr}^{79}$ Auger spectrum was done in Stockholm. The Stockholm spectrometer (of the same design) was finally adjusted to give comparable resolution but with a transmission which was about ten times larger than in the Brookhaven experiments. The Stockholm spectrometer was, however, not shimmed. The field was corrected by empirical adjustment of the coils. ${ }^{7}$ P. Erman found that, with a proper demagnetization, it is possible to achieve a resolution as good as $0.1 \%$ or better, even at an electron energy of $2 \mathrm{keV} .^{s}$ The final report on the relative intensities of the $K$ Auger lines will be published in Nuclear Physics.

\section{ACKNOWLEDGMENTS}

The authors wish to thank G. Scharff-Goldhaber and M.L. Perlman for their interest.
The excellent work of the cyclotron crew and the members of the isotope separator group of the Nobel Institute of Physics is gratefully acknowledged.

The patience and effort of $R$. Withnell and his group in preparing the thin counter windows are greatly appreciated.

\section{REFERENCES}

1. M.L. Perlman and M. McKeown, Brookhaven National Laboratory, Private communication.

2. The window thickness was measured by the method described by K. Ramarataram and D.I. Porat, Nucl. Instr. Methods 4, 239-42 (1959).

3. J.A. Davies, B. DomeiJ, and J. Uhler, Arkiv Fysik 24, 377 (1963).

4. A. Meisel and W. Nefedow, Ann. Physik 9, 48 (1961).

5. J.S. Geiger, R.L. Graham, and J.S. Merritt, Nucl. Phys. 48, 97 (1963).

6. C. J. Powell and J.B. Swan, Phys. Rev. 118,640(1960).

7. K.-E. Bergkist, Arkiv Fysik, in press.

8. P. Erman, in 1963 Annual Progress Report, Nobel Institute of Physics. 